\title{
An Analysis of Government Policies in Ensuring Food Security in Small Island Economies: A Case Study of Mauritius.
}

\author{
Needesh Ramphul, Kavi B. Nowbutsing, Hemant Birandranath Chittoo \\ University of Technology Mauritius
}

\begin{abstract}
Food security is a major concern for different countries across the world including Africa. Factors such as climate change, droughts and frequent floods, diversion of food products for production of bio fuels, piracy, and increasing demand for food products from emerging countries have led to sharp increases in the prices of food products. Many countries have been adversely affected by the increase in their food bills and they also have to face scarcity of food products due to their inability to pay. It has made people in different countries become more conscious about the importance of increasing food security within their own countries since they will not be able to influence all the factors responsible for this growing problem. Mauritius is a net food importing country due to its small size and its inability to benefit from economies of scale. It faces sharp increases in food prices and the risk of periodic scarcity of some essential commodities. In order to deal with this threat, the government has taken a lot of measures since several years. This paper has analyzed the different factors responsible for growing concern for food security in the country, the different policies adapted by the government, and the strengths and weaknesses of these strategies. Both secondary and primary data have been collected. A survey was carried out among 307 respondents in Mauritius through electronic mail to investigate different aspects of government policies and personal initiatives regarding food security. Recommendations have been proposed in order to improve the current practices. This will enable government officials of other countries to benchmark and learn from the success and failures of Mauritius in terms of food security policies.
\end{abstract}

Key Words: Food Security, Government Policy and Small Island Economies

\section{INTRODUCTION}

According to FAO (2014) report titled "The state of food insecurity in the world", there are about 805 million people who are chronically undernourished around the world. Although, the report suggests that there has been a decrease in the prevalence of undernourishment from 18.7 to 11.3 percent globally in the period 1990 - 2014, the number of people who are still undernourished is still a major concern for many countries. Despite a major improvement globally, Sub Saharan Africa has the highest level of undernourishment and there has been very modest progress in these countries in the recent years. One person out of four still suffers from undernourishment in these areas. In order to alleviate the problems related to food security, political commitment is a must and food security should be on the priority list of political parties in these countries. Food insecurity cannot be solved by only one sector or stakeholder and there should be better coordination among different stakeholders along with an enabling environment set up by government policies and leadership. However, government policies can play a major role in reducing food insecurity since they can ensure adequate investment in major projects to increase food production, encourage use of modern technology in agriculture, ensure proper coordination among different stakeholders, set up appropriate legal frameworks, initiate major institutional reforms amongst others. Government policies must be developed based on specificities of different countries since the causes of food insecurity may not be the same.

Mauritius is a small island in the Indian Ocean and it is part of the Sub Saharan Africa region. It has a population of approximately 1.2 million people. It is well known for its economic resilience despite the financial crisis in America and Europe. It also faces the problem of food insecurity as any country in this part of the world. However, Mauritius has its own specificities and context. Mauritius as an insular country depends on countries of the world for one commodity or another. The recent food crises of 2008 and 2010-2011, the increase in prices of some commodities such as fuel and grain, the rising consumption rate over production rate and extreme weather conditions are solid arguments for Government to give more serious considerations to the issue of food security (NESC report, 2013). Mauritius has limited land resources but it still produces most of its vegetables and fruits locally. However, the country still depends heavily on imports as 70 to $75 \%$ of its food requirements are imported (NESC, 2013). On the other hand, the contribution of the agricultural sector to the GDP of the country is continuously decreasing and this is an alarming factor that can lead serious problem of food security in future. 
Table 1 key indicators of imports of foods and live animals

\begin{tabular}{|l|l|l|}
\hline Key Indicators & 2012 & 2013 \\
\hline Total Imports (Rs million) & 160996 & 165594 \\
\hline $\begin{array}{l}\text { Total food and live animals } \\
\text { Imported (Rs Million) }\end{array}$ & 29792 & 31573 \\
\hline $\begin{array}{l}\text { Food and live animals as \% } \\
\text { of total imports }\end{array}$ & $18.5 \%$ & $19.1 \%$ \\
\hline $\begin{array}{l}\text { Contribution of agriculture } \\
\text { to GDP }\end{array}$ & $3.4 \%$ & $3.2 \%$ \\
\hline
\end{tabular}

Source: Statistics Mauritius (2014)

The above table shows that the imports of food and live animals out of the total imports have increased from $18.5 \%$ to $19.1 \%$. This depicts that Mauritius is increasingly becoming dependent on imports for its food and live animals. This can make Mauritius become more vulnerable to fluctuations in prices on the world Market. In addition, problems such as droughts and floods in exporting countries can also lead to availability problems of food and live animals in Mauritius. This situation is not economically good since it implies outflow of foreign currency to other countries. On the other hand, the contribution of the agriculture to GDP is decreasing year by year in Mauritius. In 2013, it only contributed to 3.2\% of GDP of the country. This can also indicate future problems in terms of food security in the island. Mauritius is a tropical island and it is often visited by severe cyclones which are detrimental for food crops and live animals. They often lead to lack of vegetables on the local markets for several months. Many customers in Mauritius are not able to afford food products since they are very expensive during these periods of scarcity. They are forced to buy canned food instead of fresh vegetables. In addition, due to the dependency of Mauritius on foreign countries for most of its food and live animals, fluctuations in world prices and world food shortages can also lead to increase in prices of food products on the Mauritian Markets (NESC, 2013).

As a result, the Mauritian government is treating the problem of food security as a priority and they have come up with different government policies and measures to tackle this problem. This paper will try to analyze the causes of food insecurity in Mauritius, the different policies adapted by the government, and the strengths and weaknesses of these strategies. Both primary and secondary data available on the measures taken by the government has been analyzed and recommendations has been made to improve on the weaknesses identified. A survey was carried out among 307 respondents in Mauritius to investigate different aspects of government policies and personal initiatives related to food security.

\subsection{Definition of Food Security}

\section{LITERATURE REVIEW}

The definition of food security has changed over time. It is not just the unavailability of food that constitute food insecurity and it takes into account different other aspects. According to FAO (2014), there are four main dimensions to the definition of food security namely; availability, access, suitability and utilization. The availability dimension captures not only the quantity, but also the quality and diversity of food. Indicators for assessing availability include the adequacy of dietary energy supply; the share of calories derived from cereals, roots and tubers; the average protein supply; the average supply of animal-source proteins; and the average value of food production. The access dimension comprises indicators of physical access and infrastructure such as railway and road density; economic access, represented by the domestic food price index; and the prevalence of undernourishment. The stability dimension is divided into two groups. The first group covers factors that measure exposure to food security risk with a diverse set of indicators such as the cereal dependency ratio, the area under irrigation, and the value of staple food imports as a percentage of total merchandise exports. The second group focuses on the incidence of shocks such as domestic food price volatility, fluctuations in domestic food supply, and political instability. The utilization dimension also falls into two groups. The first encompasses variables that determine the ability to utilize food, notably indicators of access to water and sanitation. The second group focuses on outcomes of poor food utilization, i.e. nutritional failures of children under five years of age, such as wasting, stunting and underweight.

During World food summit in 1996, they agreed that food security exist "when all people, at all times, have physical and economic access to sufficient, safe and nutritious food to meet their dietary needs and food preferences for a healthy and active life." This definition also goes beyond the availability of food and it emphasizes on safety and appropriate price of the food stuff available. In addition, they have also stressed on the cultural aspects of food since it can differ from one country to the next because of differences in belief and religious practices. These aspects of definition of food security are also endorsed by the United Nations Environment Program (UNEP, 2009). 


\subsection{Causes of Food Security in Mauritius}

Both internal and external factors impact on the problem of food security in a country. Geographic location and internal characteristics can play a vital role in explaining issues related to food security. Different causes may explain the problem of food security for different countries since the context may be different for each of them although some common causes can be identified across countries. Government must analyze the causes of food insecurity in their respective country since it will help them to come up with tailor made solutions for their particular context. In addition, some of the causal factors may not be in complete control of the government and a good example is climate change and its impact on agriculture. Different factors affecting food security in Mauritius are explained below.

\subsubsection{Climate Change}

One of the main causes of Food crisis in the world in 2008 is attributed to extreme weather conditions (ANEP, 2009).Climate change has a major influence on food production and it will inevitably lead to higher food prices, lower affordability of food and growing child malnutrition in Sub Saharan Africa (Claudia Ringler et al., 2010). In addition, severe droughts and floods are negatively affecting food production and agriculture in different parts of the world (clover, 2003). FAO is predicting that climate change will cause severe droughts in Africa and there will be approximately an additional 30 million Africans who will suffer from famine by 2050 (Clover,2003).Moreover, according to the Earth Policy research Centre (2012), extreme weather conditions will occur more frequently and country must prepare themselves to deal with this new phenomenon. The table below shows the analysis of the impact of climate change on the estimated price of staple foods by 2030 and the study was carried out by the charitable institution known as OXFAM (Sasson,2012).The study shows that climate will affect the affordability of staple food in many countries in future and humanity will be faced with resulting demographic and social crises due to rising food prices

\begin{tabular}{lcc}
\hline Crop & Without climate change (\%) & With climate change (\%) \\
\hline Paddy rice & 72 & 107 \\
\hline Wheat & 53 & 82 \\
\hline Maize & 71 & 126 \\
\hline Processed rice & 34 & 48 \\
\hline
\end{tabular}

Estimated rise in the cost of basic staples by 2030

Source; OXFAM (London based charity), Growing a better Future report (Sasson, 2012)

Mauritius is a tropical island and it is affected by severe weather conditions. Food production and Agriculture are adversely affected by frequent cyclones. In the aftermath of cyclones, vegetable prices have a tendency to rise on the local markets and government encourages importation of vegetables and fruits from foreign countries but these measures do not help to reduce the price. In addition, Mauritius has recently suffered from flash floods which are believed to be a result of climatic change in the world and it has had severe impact on prices and availability of local vegetables and fruits. In February 2013, heavy rainfall in Mauritius affected the crop sector adversely and 470 tons of vegetables had to be imported (NESC, 2013). Fall in rainfall during the past years has also been responsible for poor crop production and yield in the country. On the other hand, given that Mauritius is a net importing country, droughts and floods in countries like Australia and New Zealand has adverse effect on the prices of meat and dairy products in Mauritius since most of the importations of these food products come from these two countries. This situation shows that fluctuations in weather conditions in countries on which Mauritius depends for food will indirectly impact on prices and availability of food locally.

\subsubsection{Fluctuation in Currency}

Mauritius pays most of its imports in terms of dollars. Consequently, changes in the value of the currency have a notable impact on the prices of food products in Mauritius due to dependency on imports for food products. Economists have observed that there is a $20 \%$ increase in the price of the dollar vis a vis the Mauritian currency and they are expecting a severe increase in food prices in Mauritius in the coming months. This will affect the affordability and availability of the food on the local markets.

\subsubsection{World Market Prices}

Food world markets are more and more interrelated due to globalization and liberalization of trade. Fluctuations in prices on the world market have an impact on prices of food in all countries around the world. In 2008, the world has experienced a major food crisis leading to unexpected scarcity of food and high prices of food products on the world markets (Science magazine, 2010). Many countries restricted exportation of food

DOI: $10.9790 / 0837-2109074359 \quad$ www.iosrjournals.org $\quad 45 \mid$ Page


products so as to ensure no scarcity of food products on their respective local markets. These factors affected both availability and prices of food products around the world. In addition, world food shortages occur when consumption is higher than the production of food and the recent increase in demand for food products from developed countries have contributed in the problem. Given that Mauritius is heavily dependent on imports for its food, fluctuation on the world food market will have an indirect impact on the level of food security in the country. Mauritius depends on India and Pakistan for most its rice importations and in 2008, Mauritius feared a disruption in supply following strict measures by government of these countries to restrict export of food products. In Mauritius, rice is considered as a staple food and there is a heavy consumption from the Mauritian population because of cultural aspects customs and habit. Such fluctuations on the world markets can lead to problems of food products which are not grown locally as in the example of rice since its availability on the market depends entirely on imports. On the other hand, decrease in price for sugar on the world market has affected the economic viability of its production in Mauritius and many small farmers are abandoning their sugar cane farms. This is negatively affecting the production of sugar in Mauritius.

\subsubsection{Piracy}

Piracy in the Indian Ocean has become a growing concern for countries in the region since it is impacting on food availability and its prices. Importers of food have to pay a higher amount for insurance and freight since the insurance companies are asking for higher premiums because of threat of pirates in the region (Defi Plus, 2014). Freight can represent 40 to $50 \%$ of the final price of the imported products in the countries in the Indian Ocean. In order to maintain economic viability, increases in prices are passed on to customers. Part of increase in prices of food products in Mauritius can be explained by rising importation costs due to higher insurance premium.

\subsubsection{Diversion of Food Product for Production of Bio-Fuels}

Petroleum products are usually considered as limited in supply and scientists are trying to identify alternatives to petroleum products so as to sustain energy production around the world. One of the avenues identified is the use of food products in order to manufacture bio fuels. Such practices will inevitably affect world food supply in the coming years. For instance, Brazil is using sugar cane to manufacture ethanol as a bio fuel for cars and energy production. Such practices will usually affect world supply of food products like maize and indirectly lead to increase in prices of food products that use such products as raw materials. For instance, poultry farmers depend a lot on maize for increasing their production of live animals. Increases in the price of maize will indirectly lead to increase in price for poultry. This has been the case for Mauritius whereby producers of live animals have attributed increase in the price of their products to increase in prices of maize on the world markets.

\subsubsection{Decrease of Land available for Agriculture}

Mauritius being a small island is limited in terms of land for agriculture. However, in recent years, the government is promoting foreign investment through the conversion of agricultural land for residential purposes that are sold to foreigners who invest in Mauritius. This is one of the factors that is responsible for the decrease in the contribution of agriculture to the total GDP. Although land under agriculture has not decreased substantially, there is growing concern for identifying suitable land for agricultural purpose in Mauritius (NESC, 2013). On the other hand, the report has confirmed that there has been an increase of more than $25 \%$ of land which are being used for infrastructure, built up areas and water resources systems at the expense of agricultural land. If this trend continues in future there will be a decrease in the production of local vegetables and other crops in the island.

\subsubsection{Decrease in the Contribution of Agriculture}

Local agricultural production contributes a lot in ensuring food security in a country. It reduces dependency of a country on other countries for its food. Hence, changes on the world market will have less impact on food security in a country if most of its food supply comes from its local production. Less money is spent on transportation, storage and distribution of food. It can reduce the impact of external forces on food security in a country. Mauritius is a net food importing country and it is affected by changes in external factors. This can affect both availability and affordability of food products. It has been observed that the contribution of the agricultural sector is decreasing year by year (as shown in the statistics above). Many reasons account for the decrease in crop production locally. Young people are no longer interested to join the agricultural sector in Mauritius and most of the farmers are from the old generation that depends a lot on traditional ways of agriculture. Fruit production is affected in Mauritius due to a growing number of local bats which are protected by the government. They destroy lot of fruits in Mauritius and farmers can not kill them since they are protected in our country. In addition, extreme weather conditions in our country can also explain a decrease in the yield of 
crops in Mauritius. As far as sugar production is concerned, many small farmers are abandoning their field since world prices of sugar are on a decline and it has reduced the viability of its production in Mauritius.

\subsection{Government Policies in Mauritius}

The government has come up with two strategic plans in order to deal with the problem of Food security since 2008. The first one was set up for the period 2008 till 2011 and the second one was set up for 2013 till 2015. The strategic plan 2008 to 2011 was launched by the Ministry of Agro Industry and Food Security to; increase production of priority crops; maintain self-sufficiency level in poultry meat and fresh vegetables; introduce new protein-rich crops (soybean); provide more land for production of foodstuffs; encourage the regrouping of small-scale farmers; achieve a higher self-sufficiency level in the production of fresh milk and meat; sensitize the population on the benefits of eating healthy foods; mitigate the marketing constraints encountered by small food crop farmers; and partner with regional countries for the production of selected commodities (potato, maize, rice, onion and pulses). It is noted that the plan was successful to a certain extent since both crop and live stock production increased during the period. Crop production increased by $23.7 \%$ while Meat production increased by $53 \%$ in the period 2008-2011. Potato production increased by $45 \%$ in the same period whereas milk production increased by $37 \%$ and these can be attributed to the implementation of the plan (Strategic plan 2013-2015).

The food security strategic plan 2013 to 2015 was prepared as a continuation of the previous plan. It has been developed after analyzing shortcomings of the previous plan and the lessons learnt from past experiences in the sector. It also takes into consideration all challenges facing the agricultural sector and the current trends observed in the agro-industry. The main objectives of the plan is to improve the level of self sufficiency in various commodities, promote export and create new opportunities for farmers, entrepreneurs and rural families to increase farm income and productivity while conserving the natural biodiversity and providing safe, sufficient and nutritious food supply. The plan recognizes that it is unrealistic to achieve $100 \%$ self sufficiency in food production due to scarcity of land and targets a realistic 33\% self-sufficiency in food production. However, the decrease in the contribution of the agricultural sector to the GDP highlights that there has been a decrease in food production and highlights weaknesses of the plan although one year is still left in its implementation. However, there has been some positive impacts of the plan as well since Mauritius has been able to achieve self sufficiency in potato production and Poultry products in the recent years.

\subsubsection{Increase in Selected Crop Production}

The government has recognized that it is very difficult to achieve $100 \%$ self sufficiency in terms of food production. Consequently, the government has targeted selected crops for which production can be increased and reliance on imports can be reduced. Incentives have been provided to farmers to adopt these crops and contribute in its production. One success story is the production of Potatoes in Mauritius. Its production has substantially increased and Mauritius is nowadays self sufficient in terms of potato production. Government has provided appropriate training to planters through the ministry of agriculture, given seeds to planters at a cheaper price and at the same time officers of the ministry has monitored its production together with planters. Officers advise planters on diseases and usually suggest to adapt a rotation policy so that they do not plant potato in the same land each year. This has enabled to reduce the risk of disease and hence contributed in improving its productivity. In addition, planters were also given opportunity to mechanize their production practices with the help of the government whereby they can rent agricultural equipment at a cheaper rate from semi governmental organizations in Mauritius. To achieve the 33\% set target in 2015, it proposed that 1,075ha of agricultural land be initially released to increase production of onion, potato, garlic, maize, fruits and fodder / pasture for meat and milk production.

\subsubsection{Training of Farmers and Youth}

In Mauritius, farming is mainly done according to the traditional ways. Government has found that in order to increase food production, it is very vital to provide training to small farmers so that they can use the latest technology and the latest techniques in food production. On the other hand, it has been found that the community of farmers in Mauritius is ageing year by year and the new generation is no longer interested in joining the sector. This will inevitably lead to a fall in food production in future. In this context, the government is motivating the youth to join the sector but they must learn the new ways of engaging in food production. Many schools have already their own hydroponic culture and they encourage students in planting food crops in them. Training is also being provided to people in poverty stricken areas to start home gardening so that they can meet their requirements of food to some extent.

\subsubsection{Mechanization and Modernization of the Agricultural Sector}

Another factor that may adversely affect the Mauritian agricultural sector in future is the ageing population of agricultural workers in the sector. Young people are no longer interested to work as agricultural 
workers and they usually prefer to get a white collar job or work in the tourism sector in Mauritius. The lack of local workers has led to an increase in labour costs in the sector contributing a lot in the increase of cost of production of food in Mauritius. Many planters complain that they cannot increase production due to lack of local workers. One of the solution to this problem is the promotion of mechanization in the sector. Given the mechanization can be costly, the government has set up the small farmers mechanical pool so that planters can benefit from mechanization and to some extent alleviate the problem of labour in the sector. Farmers are also being encouraged to move from open farming to protected farming whereby the impact of climate can be controlled. Incentives are being provided so that they can adopt hydroponic culture for food production with a view to shift from traditional farming to modern farming techniques. This shift can also contribute in increasing food production in future.

\subsubsection{Incentives to Farmers}

Different incentives are being provided to small farmers to increase food production in Mauritius. Seeds for certain crops like potato, garlic, onions amongst others are being provided to farmers at a guaranteed and preferential price so as to encourage farmers to engage in the production of these food crops. Financial facilities in terms of loan for purchasing of machinery for land preparation, irrigation and harvesting are being given to planters. Mechanical land preparation is being encouraged among small farmers to increase the yields. Free training is provided to farmers concerning the ways to plant the crop, deal with different diseases, harvesting and storage of different crops. Free compost bags and seeds are given to small planters so that they can restart production after floods and cyclones.

\subsubsection{Development of Agribusiness}

In Mauritius, there are periods whereby there may be excess of vegetables on the markets. Farmers do not harvest the vegetables in such situations since it is not economically viable and this may be wasted. Consequently, government is trying to promote agro-processing whereby some vegetables can be used as raw materials for these agro-processing firms. One example is the case of tomatoes whereby Mauritius encounters situations where there is high supply on the markets and after cyclones, Mauritius suffers from the scarcity of the same product and has to import canned tomatoes to service the local market. On the other hand, government is encouraging private initiatives to produce flour from cassava, bread fruit and banana. In addition, farmers are encouraged to produce more fruits and other local vegetables which can be used to manufacture jam and pickles which are mostly imported from other countries.

\subsubsection{Use of Land available in Neighbouring Countries}

Given that land is major limitation for agriculture in Mauritius, Mauritius has encouraged farmers to use their knowhow and use land which are provided by governments from other countries like Madagascar and Mozambique. Mauritian potato planters are already present in Madagascar and some of their production is exported to Mauritius. This may be a risk especially if the political stability cannot be ensured. Mauritian sugar producers are also present in different countries in Africa and planting sugar cane on a large scale has enabled them to benefit from economies of scale.

\subsubsection{Provision of Nets for Protection Against Bats}

Fruit production has gone down in recent years and this has been attributed mainly to the increase in the number of bat population in Mauritius. Given that they are among the protected species of animal in Mauritius, it is not lawful to kill them. Fruit growers have lot of difficulty in dealing with them and lots of measures have been taken to reduce the impact of this problem. Government is offering protective net at a reduced price to fruit growers so that they can protect their orchards against the bats.

\subsubsection{Development of the Ocean Economy}

The government of Mauritius has decided to set up an ocean economy as another pillar of the economy that can contribute to the GDP in addition to the traditional sectors and use the large marine resources at its disposal. This measure will also help to reduce the problem of food security since measures are being taken to increase fish production. Aquaculture is being promoted among local fishermen since this will enable them to sustain their fish production. Training and necessary incentives are being provided to them so that they regroup themselves in cooperatives and help each other in such initiatives. Production of oysters and crabs are also being encouraged on a larger scale and this can also help to meet the local demand for such products. Deep sea fishing is being encouraged among local fishermen so that local fishermen can increase their fish catch as inner lagoon is almost depleted. However, such initiatives have also been criticized since some local fishermen believe that aquaculture can have adverse environmental impact and it can cause further damage to our marine ecology. Illegal fishing in the jurisdiction of Mauritius by foreign vessel is also another major problem due to lack of 
proper control from the Mauritian Marine authorities. The Mauritian government has recently acquired a ship which has the latest technology to keep a closer control on the marine resources of Mauritius and this will also help to boost up fish availability on the local market.

\section{RESEARCH METHODOLOGY}

This section explores the methodology used to study issues relating to food security in Mauritius. In particular, two methods are proposed. Firstly, secondary data are collected to reflect on climate change, land use and crop production, fish production, import intensity for livestock, food price index and agricultural share in GDP and employment. Secondly, survey methodology is used to capture public awareness of food security in Mauritius as well as to examine public perceptions on the effectiveness and/or inadequacy of Government policies. Moreover, the survey addresses individual behaviour as regards consumption and self-supply for vegetables, fruits and animals.

\subsection{Secondary data}

Data are firstly collected through desk study on food security related information in Mauritius, in particular historic data are collected for variables describe below. The purpose is to build a good understanding of the food security situation and to uncover data gaps. More specifically, secondary data helps in uncovering long-term socio-economic trends.

\begin{tabular}{|l|l|l|}
\hline Variables & Description & Source \\
\hline Rainfall & $\begin{array}{l}\text { Average monthly rainfall for the island of } \\
\text { Mauritius reported in millimeters }\end{array}$ & $\begin{array}{l}\text { Mauritius } \\
\text { Services }\end{array}$ \\
\hline Temperature & $\begin{array}{l}\text { Average monthly temperature for the } \\
\text { island of Mauritius reported in }{ }^{0} \mathrm{C}\end{array}$ & $\begin{array}{l}\text { Climatic Research Unit (CRU) } \\
\text { of University of East Anglia }\end{array}$ \\
\hline $\begin{array}{l}\text { Area harvested } \\
\text { and production } \\
\text { of food crops }\end{array}$ & $\begin{array}{l}\text { Land area harvested in hectares and food } \\
\text { crops production in tonnes, yearly from } \\
1980 \text { to 2013 }\end{array}$ & Ministry of Agriculture \\
\hline $\begin{array}{l}\text { Fish } \\
\text { production }\end{array}$ & $\begin{array}{l}\text { Production of fish in tonnes, yearly from } \\
1980 \text { to 2013 }\end{array}$ & Ministry of Fisheries \\
\hline Livestock & $\begin{array}{l}\text { Livestock slaughtered (No. of heads) for } \\
\text { cattle, goats, sheep and pigs }\end{array}$ & Mauritius Meat Authority \\
\hline $\begin{array}{l}\text { Contribution } \\
\text { of agriculture }\end{array}$ & $\begin{array}{l}\text { Share of agriculture in GDP, share of } \\
\text { sugar in agriculture, share of agriculture in } \\
\text { total employment }\end{array}$ & Statistics Mauritius \\
\hline $\begin{array}{l}\text { Producer price } \\
\text { index }\end{array}$ & $\begin{array}{l}\text { The Producer Price Index-Agriculture } \\
\text { (base year 2007) gives a measure of the } \\
\text { average change in the selling prices which } \\
\text { producers receive for their agricultural } \\
\text { products. The bulk of the products in } \\
\text { agriculture, with the exception of forestry, } \\
\text { fishing and agricultural services, is taken } \\
\text { into account in the producer price index. }\end{array}$ & \\
\hline
\end{tabular}

\subsection{Survey Design}

A survey is generally effective in capturing perceptions, opinions and views of respondents. In the present study, a survey is design to complement secondary data findings through generation of data on public perceptions on Food Security, effectiveness and adequacy of Government policies, causes of food insecurity, and individual engagement in agricultural activities. A semi-structured questionnaire is designed to map:

(i) Profiles of respondent in terms of gender and age group. Other controls such as region, ethnicity, and income levels are not included in order to keep the questionnaire manageable.

(ii) Question is set to measure understandability of the term food security, namely: availability, affordability, stability and suitability.

(iii) Questions on causes of food insecurity are formulated to measure perceived impact of: climate change, fluctuation in currency, fluctuation in world price, piracy, diversion of food product for production of bio-fuels, decrease in land available for agriculture, decrease in the contribution of agriculture to GDP, and other.

(iv) A list of statements to capture public knowledge on existing government policies including, encouragement to selected crop production, training of farmers and the youth, mechanization and modernization of agricultural sector, incentives to farmers, development of agri-business, use of land in neighboring countries, provision of nets for protection against bats, development of the ocean economy, and other. 
(v) A list of SEVEN statements to measure effectiveness, ineffectiveness and expectations on government policies.

(vi) A list of FIVE statements to understand individual consumption and/or self-supply behaviour as regards food crops and animals.

\subsection{Sampling Methodology and Size}

A convenient sampling methodology was used for the survey due to time constraints. Given that food security is a concern for everybody in society, different stakeholders namely customers, policy makers, government officials, farmers, fruit and vegetable sellers amongst others were considered. The questionnaire was administered by electronic mails to a target of 500 population over the month of April 2015. However, only 307 responses were recorded.

\section{ANALYSIS AND DISCUSSIONS}

This section initially discusses the trends in variables identified under secondary data methodology with a view to infer on Food Security issues and concerns for Mauritius. At a second stage, survey data are analyzed to capture public perceptions on the term Food Security, effectiveness and adequacy of Government policies, causes of food insecurity, and individual engagement in agricultural activities.

\subsection{Trends in climate Change}

Impacts of climate change cannot be ignored in the context of small island economies like Mauritius. It can also be argued that agricultural activities, especially crop and fish productions, are adversely affected by climate change. Table 2 below presents the mean rainfall for Mauritius on a monthly basis and compares rainfall for 2012 and 2013 to a base period of 1971-2000, in terms of mean deviation. The results confirm a mean deviation in the range of -172 to $87 \mathrm{~mm}$ for 2012 and -107 to $147 \mathrm{~mm}$ for 2013 . The changing pattern in rainfall has also been observed recently, in particular on $30^{\text {th }}$ March 2013 sudden rains causing flooding, infrastructural damage and death. BBC News of $31^{\text {st }}$ March 2013 reported that "At least 11 people have died after sudden rains caused flooding in the Mauritian capital Port Louis on Saturday... The island's meteorologists said 152mm (6in) of rain fell in less than an hour, 70mm less than the March average". The impact was such that the $1^{\text {st }}$ April 2013 was declared a day of mourning and public declaration associated sudden rains to effects of climate change.

Table 2: Mean rainfall deviation for Mauritius (in Millimeters)

\begin{tabular}{|c|c|c|c|}
\hline \multirow{2}{*}{ Month } & \multirow{2}{*}{$\begin{array}{c}\text { Mean } \\
(\mathbf{1 9 7 1 -} \\
\mathbf{2 0 0 0 )}\end{array}$} & \multicolumn{2}{|c|}{ Mean deviation } \\
\cline { 3 - 4 } & 261 & $\mathbf{2 0 1 2}$ & $\mathbf{2 0 1 3}$ \\
\hline Jan & $26172)$ & $(15)$ \\
\hline Feb & 336 & $(112)$ & 127 \\
\hline Mar & 242 & 87 & 96 \\
\hline Apr & 226 & 12 & $(18)$ \\
\hline May & 159 & 20 & $(107)$ \\
\hline Jun & 115 & $(41)$ & $(43)$ \\
\hline Jul & 120 & $(14)$ & $(54)$ \\
\hline Aug & 122 & $(46)$ & $(20)$ \\
\hline Sep & 81 & $(30)$ & $(43)$ \\
\hline Oct & 70 & $(23)$ & 62 \\
\hline Nov & 80 & $(10)$ & 147 \\
\hline Dec & 199 & $(73)$ & $(94)$ \\
\hline Year & 2,011 & $(402)$ & 38 \\
\hline
\end{tabular}

Source: Mauritius Meteorological

Services
Table 3: Average monthly temperature $\left({ }^{0} \mathrm{C}\right)$

\begin{tabular}{|l|r|r|r|}
\hline Month & $\begin{array}{c}\text { 1930- } \\
\text { 1960 }\end{array}$ & 1960-1990 & 1990-2009 \\
\hline Jan & 25.3 & 25.2 & 25.7 \\
\hline Feb & 25.3 & 25.3 & 25.8 \\
\hline Mar & 25.2 & 25.1 & 25.5 \\
\hline Apr & 24.2 & 24.2 & 24.7 \\
\hline May & 22.6 & 22.5 & 23 \\
\hline Jun & 20.9 & 21 & 21.3 \\
\hline Jul & 20 & 20.1 & 20.4 \\
\hline Aug & 19.9 & 19.9 & 20.4 \\
\hline Sep & 20.6 & 20.5 & 21 \\
\hline Oct & 21.7 & 21.6 & 22 \\
\hline Nov & 23.1 & 23.1 & 23.5 \\
\hline Dec & 24.4 & 24.4 & 24.7 \\
\hline
\end{tabular}

Source: Climatic Research Unit, University of

East Anglia

The climate change captured by average monthly temperature is given in table 3 . It can be argued that while temperature for period 1930-1960 and 1960-1990 only varied between -0.1 and $0.1\left({ }^{0} \mathrm{C}\right)$. Conversely, the global warming phenomenon is quite obvious for the latter period, i.e. 1990-2009, with an average increase in 
temperature in the range of 0.3 to $0.5\left({ }^{0} \mathrm{C}\right.$ ). The highest increase (i.e. $0.5{ }^{0} \mathrm{C}$ ) is observed for the month of February, April and August and lowest increase (i.e. $0.3{ }^{0} \mathrm{C}$ ) occurs in December.

\subsection{Land Use, Food Crops, Fish and Livestock Production}

In general input-output analysis would posit crop production as directly or positively dependent on land use (measured by area harvested). Table 3 shows a two-fold increase land use and a three-fold increase in food crops production. Altogether, these implied an increase in crop yield from 10 tonnes per hectare in 1980 to 14 tonnes per hectare in 2013.

Table 3: Land use and production of food crops

\begin{tabular}{|l|c|c|c|}
\hline Year & $\begin{array}{c}\text { Area } \\
\text { Harvested } \\
\text { (hectare) }\end{array}$ & $\begin{array}{c}\text { Food crops } \\
\text { Production } \\
\text { (tonnes) }\end{array}$ & $\begin{array}{c}\text { Yield } \\
\text { (tonnes/hectare) }\end{array}$ \\
\hline 1980 & 3,819 & 39,450 & 10 \\
\hline 1985 & 5,339 & 67,195 & 13 \\
\hline 1990 & 5,699 & 65,840 & 12 \\
\hline 1995 & 6,769 & 97,533 & 14 \\
\hline 2000 & 7,357 & 114,484 & 16 \\
\hline 2005 & 6,901 & 96,782 & 14 \\
\hline 2010 & 7,570 & 114,844 & 15 \\
\hline 2013 & 8,189 & 118,121 & 14 \\
\hline
\end{tabular}

Source: Extension Division (Ministry of Agriculture) up to1997; AREU as from 1998; FAREI as from 2013

Table 4 on fish production reveals a general downward trend in both 'high seas' and 'coastal' fishing. On one hand, it is interesting to note that Mauritius has an Exclusive Economic Zone which is equivalent to 1.9 million $\mathrm{Km}$, thus representing a considerable potential for development of marine related activities, including 'high seas' fishing. On the other, similar to IFAD (2005) the above table confirms that lagoon fishers faced with constantly declining catches. Lastly, prospects for increased "ponds and barachois" fish production remain plausible in Mauritius. Overall the need for increasing fish production is imminent given that small scale fishing activities are mostly undertaken at the level of coastal communities, which are often plagued by poverty, low education and lack of other economic activities, amongst others.

Table 4: Fish production (tonnes)

\begin{tabular}{|c|c|c|c|c|}
\hline Year & High seas & $\begin{array}{c}\text { Coastal } \\
\text { fishing }\end{array}$ & $\begin{array}{c}\text { Ponds and } \\
\text { barachois }\end{array}$ & Total \\
\hline 1980 & 4,882 & 1,935 & 27 & 6,844 \\
\hline 1985 & 11,629 & 2,034 & 35 & 13,698 \\
\hline 1990 & 10,568 & 2,587 & 67 & 13,222 \\
\hline 1995 & 12,618 & 2,393 & 170 & 15,181 \\
\hline 2000 & 5,468 & 2,310 & 64 & 7,842 \\
\hline 2005 & 6,711 & 1,897 & 374 & 8,982 \\
\hline 2010 & 3,214 & 2,112 & 561 & 5,887 \\
\hline 2013 & 3,625 & 1,749 & 421 & 5,795 \\
\hline
\end{tabular}

Source: Ministry of Fisheries

In terms of livestock, self-sufficiency is generally observed in the case of poultry and pigs production. For sheep production, local production has been drastically falling, thus, signaling increased dependence on import for meat. The dependence on imports for cattle is more pronounced than for any other livestock, reaching $94 \%$ in 2013. Lastly, in the case of goats which were fully-domestically produced up to 1990 the rise in import can be observed, reaching $20 \%$ in 2013. 
Table 5: Livestock slaughtered (no. of heads)

\begin{tabular}{|c|c|c|c|c|c|c|}
\hline \multirow{2}{*}{ Year } & \multicolumn{2}{|c|}{ Cattle } & \multicolumn{2}{c|}{ Goats } & \multirow{2}{*}{ Pheep } & \multirow{2}{*}{ Pigs } \\
\cline { 2 - 5 } & Total & $\begin{array}{c}\text { Import } \\
(\%)\end{array}$ & Total & $\begin{array}{c}\text { Import } \\
(\%)\end{array}$ & & \\
\hline 1980 & 10,181 & 68 & 13,960 & n/a & 4,138 & 9,200 \\
\hline 1985 & 5,088 & 34 & 19,873 & n/a & 2,058 & 11,731 \\
\hline 1990 & 12,913 & 76 & 14,752 & 35 & 2,642 & 11,949 \\
\hline 1995 & 10,726 & 70 & 13,793 & 32 & 1,005 & 15,419 \\
\hline 2000 & 11,869 & 86 & 9,545 & 23 & 1,271 & 12,146 \\
\hline 2005 & 11,052 & 96 & 7,870 & 56 & 370 & 10,011 \\
\hline 2010 & 8,473 & 95 & 5,243 & 34 & 841 & 8,886 \\
\hline 2013 & 8,884 & 94 & 4,679 & 20 & 318 & 9,656 \\
\hline
\end{tabular}

Source: Mauritius Meat Authority

\subsection{Contribution of agriculture and producer price index}

Although Mauritius was an agriculture based economy (mainly sugar) before industrialization policies in the seventies and eighties, over decades the shrinking contribution of agriculture to GDP and employment is clearly visible. Table 6 shows the share of agriculture to have reached a level low of $3.3 \%$ in 2013, out of which sugar accounted for almost one-third (32.1\%). In terms of employment the agricultural sector occupies for a still significant share of $8 \%$ of the labour force.

Table 6: Contribution of agricultural sector

\begin{tabular}{|c|c|c|c|c|}
\hline Year & $\begin{array}{c}\text { Share of } \\
\text { agriculture } \\
\text { (\% GDP) }\end{array}$ & $\begin{array}{c}\text { Share of } \\
\text { sugar (\% } \\
\text { agriculture) }\end{array}$ & $\begin{array}{c}\text { Employment } \\
\text { ('000) }\end{array}$ & $\begin{array}{c}\text { Share of } \\
\text { agriculture } \\
\text { (\% total } \\
\text { employment) }\end{array}$ \\
\hline 1995 & 9.7 & 61.0 & 61.6 & 13.4 \\
\hline 2000 & 6.8 & 52.4 & 55.8 & 11.5 \\
\hline 2005 & 6.0 & 53.2 & 48.7 & 9.6 \\
\hline 2010 & 3.6 & 32.3 & 47.7 & 8.5 \\
\hline 2013 & 3.3 & 32.1 & 44.2 & 8.0 \\
\hline
\end{tabular}

Moreover, figure 1 presents the producer price index four previous years on a quarterly basis. The figure reveals significant variation in producer prices across quarters and supports the contention that price instability is a serious cause for concerns to the extent that it leads to fluctuation of revenue for people engaged in agricultural activities as well as fluctuation of expenditure for household consumers of agricultural products.

Figure 1: Producer price index (at 2007 base-year prices) 


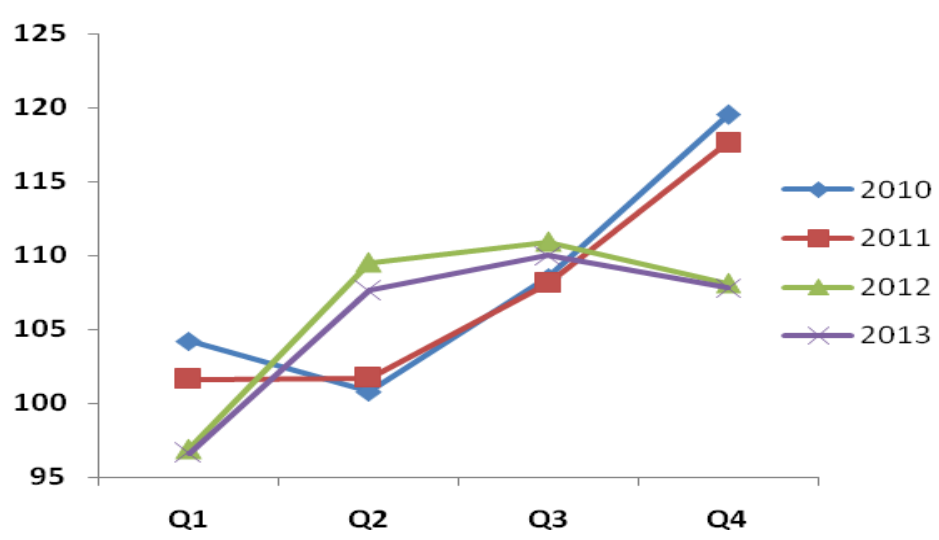

Source: Statistics Mauritius

\subsection{Profiles of Respondents}

From this section onwards the survey data are presented. First, we discuss on the composition of the sample. Notably, the number of respondents is fairly spread between male and female with a percentage share of $52 \%$ and $48 \%$, respectively. Moreover, representation across age groups are as follows: $75 \%$ of respondents are between 18 to 34 years, $14 \%$ of respondents in the age group 35-44 years, $6 \%$ of respondents are in the age group 45-54 years, and 5\% in the above 55 years age category. Given that low participation s was recorded of higher age group can be associated to the fact that these groups may be less active on internet and electronic mail.

Table 7: Respondents profile (gender and age group)

\begin{tabular}{|c|r|r|r|r|r|}
\hline \multirow{2}{*}{ Gender } & \multicolumn{4}{|c|}{ Age group } & \multirow{2}{*}{ Total } \\
\cline { 2 - 5 } & 18-34yrs & 35-44yrs & 45-54yrs & 55-64yrs & Total \\
\hline Male & 103 & 19 & 14 & 10 & 146 \\
Female & 126 & 23 & 8 & 4 & 161 \\
Total & 229 & 42 & 22 & 14 & 307 \\
\hline
\end{tabular}

\subsection{Perceptions on Food Security}

From the findings it is observed that a comfortable majority of people (or 87\%) agrees to the broadest definitions of Food Security that is implying that food is available, affordable, stable and suitable.

Figure 2: What is food security 


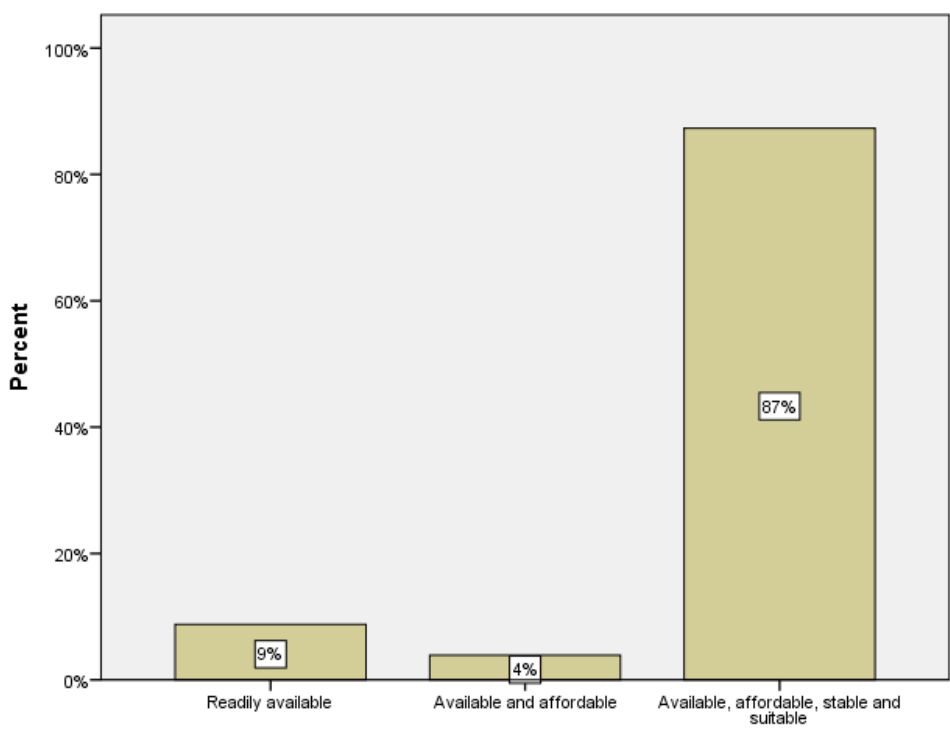

Moreover, figure below gives the perceptions of public on food security in Mauritius and results show that almost $70 \%$ of respondents rejected the claim of food security. The implications can be complex since it may imply that food could be either unavailable or unaffordable or unstable or unsuitable.

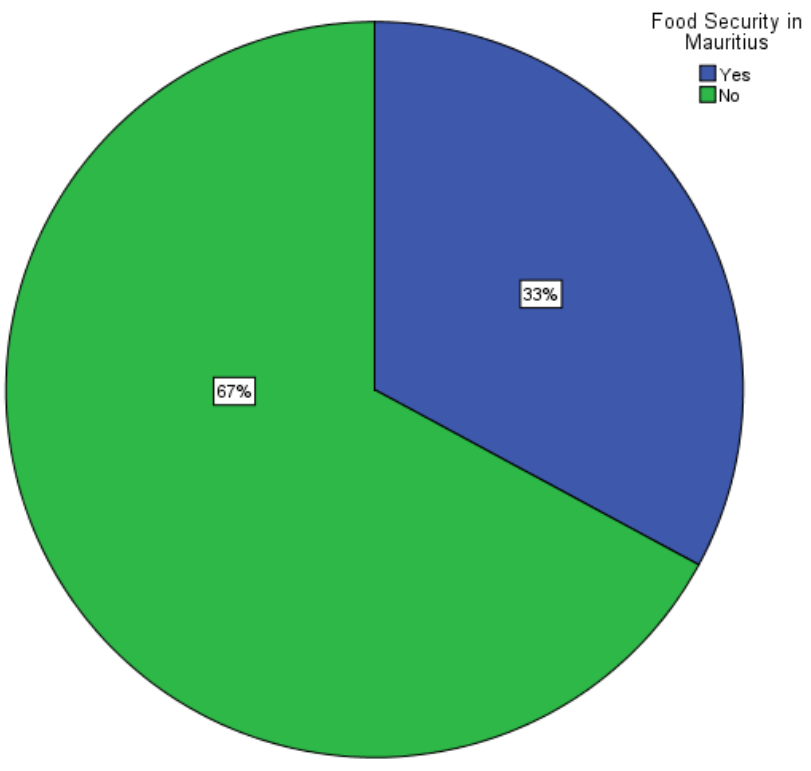

Furthermore, public opinions on causes of food insecurity in Mauritius revealed the following:

$\begin{array}{clr}\text { Rank } & \text { Causes } & \% \\ 1 & \text { Climate change } & 71 \\ 2 & \text { Fluctuation in world prices } & 50 \\ 2 & \text { Decrease in land available for agriculture } & 50 \\ 3 & \text { Fluctuation in currency } & 38 \\ 3 & \text { Decrease in contribution of agriculture to GDP } & 38 \\ 4 & \text { Diversion of food product for production of bio fuels } & 23 \\ 5 & \text { Piracy } & 4 \\ 6 & \text { Other } & 3\end{array}$


Therefore, it can be argued that climate change is considered to be the most important cause of food insecurity followed by fluctuation in world prices, and decrease in land available for agriculture.

\subsection{Perceptions on Policy Effectiveness}

To understand how effective government policies are in the eyes of the public the results of table 8 are discussed. In particular, we cross-tabulate responses for question "government policies have been effective in increasing food and meat production in Mauritius" and "government policies have been ineffective in increasing food and meat production in Mauritius". Since the two questions are perfectly-inversely related, it is expected that people who agree to one would disagree to the second. However, results show that only 51 (out of 307) who agree on "effectiveness of policy" also disagree to "ineffectiveness of policy".

Table 8: Effectiveness of Government policies

\begin{tabular}{|c|c|c|c|c|c|c|}
\hline & & \multicolumn{4}{|c|}{$\begin{array}{l}\text { Ineffectiveness of Government } \\
\text { policies }\end{array}$} & \multirow[b]{2}{*}{ Total } \\
\hline & & $\begin{array}{c}\text { Disagre } \\
\mathrm{e}\end{array}$ & Neutral & Agree & $\begin{array}{c}\text { Disagre } \\
\mathrm{e}\end{array}$ & \\
\hline \multirow{5}{*}{$\begin{array}{l}\text { Effectiveness of } \\
\text { Government } \\
\text { policies }\end{array}$} & $\begin{array}{l}\text { Strongly } \\
\text { disagree }\end{array}$ & 4 & 0 & 5 & 4 & 13 \\
\hline & Disagree & 9 & 0 & 44 & 10 & 63 \\
\hline & Neutral & 8 & 81 & 33 & 4 & 126 \\
\hline & Agree & 51 & 40 & 0 & 0 & 91 \\
\hline & Disagree & 0 & 0 & 0 & 14 & 14 \\
\hline Total & & 72 & 121 & 82 & 32 & 307 \\
\hline
\end{tabular}

The above findings imply confused public opinions on the effectiveness of government policies. To assess the reliability of the findings a correlation analysis is produced in table 9 for the two questions. Importantly, a negative, significant, but weak correlation (-29\%) is observed between policy effectiveness and ineffectiveness. Therefore, it can be inferred that public have a confused opinion on the effectiveness of government support to the agricultural sector.

Table 9: Correlation between policy effectiveness and policy ineffectiveness

\begin{tabular}{|ll|r|r|}
\hline & $\begin{array}{c}\text { Effectiveness } \\
\text { of Government } \\
\text { policies }\end{array}$ & $\begin{array}{l}\text { Ineffectiveness } \\
\text { of Government } \\
\text { policies }\end{array}$ \\
\hline $\begin{array}{l}\text { Effectiveness of } \\
\text { Government policies }\end{array}$ & Pearson Correlation & 1 & $-.288^{* *}$ \\
& Sig. (2-tailed) & $\mathrm{N}$ & .000 \\
Ineffectiveness of & Pearson Correlation & $-.288^{* *}$ & 307 \\
Government policies & Sig. (2-tailed) & .000 & 1 \\
& $\mathrm{~N}$ & 307 & 307 \\
\hline
\end{tabular}

**. Correlation is significant at the 0.01 level (2-tailed).

Lastly to assess the extent to which public are aware of government policies are programs the following table is presented and ranked in order of public importance. 


$\begin{array}{llr}\text { Rank } & \text { Existing Government policies } & \% \\ 1 & \text { Incentives to farmers } & 78 \\ 2 & \text { Training of farmers and the youth } & 62 \\ 3 & \text { Mechanization and modernization of agricultural sector } & 55 \\ 4 & \text { Development of agribusiness } & 52 \\ 5 & \text { Development of the Ocean economy } & 46 \\ 6 & \text { Increase in selected crop production } & 35 \\ 7 & \text { Provision of nets for protection against bats } & 22 \\ 8 & \text { Use of land in neighboring countries } & 9\end{array}$

\subsection{Expectations on Government Support}

In terms of public expectations on government support lending to food security in Mauritius, it can be argued that respondents tend to significantly agree to all statements. Nevertheless, in order of priority it can be argued that the mean score is highest for government to sensitize on healthy-eating and food wastage (4.52 and 4.42 , respectively). Note that the one-sample t-test statistics comparing the mean score to a test value of 3 (representing neither agree nor disagree) on a Likert scale from 1(strongly disagree) to 5 (strongly agree). The one-sample t-test table is presented at annex.

Table 10: Mean comparison (Expectations on Government support)

\begin{tabular}{|l|l|l|l|}
\hline Statement & Mean & $\begin{array}{l}\text { Std. } \\
\text { Deviation }\end{array}$ & $\begin{array}{l}\text { Std. Error } \\
\text { Mean }\end{array}$ \\
\hline $\begin{array}{l}\text { More incentives from Government to planters and } \\
\text { farmers }\end{array}$ & 4.11 & .989 & .056 \\
$\begin{array}{l}\text { More training from Government to planters and } \\
\text { farmers }\end{array}$ & 4.23 & .913 & .052 \\
$\begin{array}{l}\text { Government to encourage youth participation in } \\
\text { agri-businesses }\end{array}$ & 4.18 & .919 & .052 \\
Government to sensitize on food wastage & 4.42 & .798 & .046 \\
Government to sensitize on healthy-eating & 4.52 & .879 & .050 \\
\hline
\end{tabular}

\subsection{Individuals Consumption and/or self-supply Behavior}

In terms of individual consumption patterns of food crops and animals, from figure 11, it can be argued that public opinions tend to significantly agree on (i) food purchasing from market only, (ii) vegetables requirements partly met by home gardening, (iii) gardening of fruit trees, and (iv), they do not have time for agricultural activities. In contrast, public opinions tend to disagree on rearing animals for self-consumption. Note the one-sample t-test statistics is presented at annex 2. 
Table 11: Mean comparison (Individuals consumption and/or self-supply behaviour)

\begin{tabular}{|c|c|c|c|}
\hline Statement & Mean & Std. Deviation & Std. Error Mean \\
\hline Food purchasing from market only & 3.36 & 1.127 & .064 \\
\hline $\begin{array}{l}\text { Vegetables requirements partly met } \\
\text { by home gardening }\end{array}$ & 3.48 & .998 & .057 \\
\hline Gardening fruit trees & 3.69 & 1.053 & .060 \\
\hline Rearing animals for self-consumption & 2.54 & 1.129 & .064 \\
\hline $\begin{array}{l}\text { Do not have time for subsistence } \\
\text { agriculture }\end{array}$ & 3.41 & 1.106 & .063 \\
\hline
\end{tabular}

\section{RECOMMENDATIONS}

\subsection{Provide more Land for Food Production}

As per the strategic plan developed by the Ministry of Agriculture, land is a limiting factor for more food production in Mauritius. In addition, agricultural land is being converted to land for residential and commercial purposes. Consequently, in order to increase food production in Mauritius, more land should be earmarked for crop production and livestock. This can be achieved by identifying all the land that is being abandoned by sugar planters and developing a proper database so as to encourage the land owners to rent their land for crop production and livestock. The database can be provided to planters who want to have more land to increase their crop production.

On the other hand, many countries in the regions are interested to provide land to Mauritius so as to encourage investment from Mauritian in their countries. For instance, Mozambique has earmarked many 23500 hectares of land for Mauritius (NESC, 2013). International visits to these areas can be encouraged by the Mauritian government for small planters or cooperatives engaged in food production and livestock breeding in Mauritius. This will enable them to identify opportunities that exist in other countries in order to increase food production which can be exported to Mauritius. This exercise can be undertaken by the board of investment and the Regional Development Co. LTD which are governmental organizations responsible for encouraging investment in and outside Mauritius. This will enable Mauritian farmers to use their expertise in increasing food production in this sub Saharan African region. In addition, the Mauritian government can buy the production of these farmers through the agricultural marketing board at a guaranteed price and this will give the framers additional incentives to start production in these neighboring countries. This can help to reduce the cost of food to Mauritius since transport cost can be reduced and planters doing farming on a larger scale can reduce their cost of production due to economies of scale and cheap labour available in these countries.

\subsection{Agriculture as Part of the School Curriculum at Primary, Secondary and Tertiary Levels.}

It has been found that less young people are interested to join the agricultural sector and the workforce in the agricultural sector in Mauritius is ageing. In this context, government must motivate young people to take interest in the agricultural sector. This can help to reduce unemployment in the country as well as increase food production in future. The importance of agriculture can to be inculcated at a very young age to people and hence it should be included in the educational curriculum at primary, secondary and tertiary level. Students at the primary level can be trained in gardening and this can be part of extracurricular activities organized in the school. At secondary level, agriculture must be taught to all students and setting up of agricultural clubs can be encouraged. In addition, government can finance a hydroponic facility in every secondary school of the country to inculcate new ways of engaging in food production. The concept of agribusiness must be promoted at the tertiary level so that more young people can be interested to start degrees in this field. 


\subsection{Motivate People to Start Home Gardening}

The Mauritian government must motivate people in the country to start home gardening. This can also contribute in reducing food insecurity in Mauritius. Advertising campaigns in the press and national television can be done to highlight the advantages of home gardening to the Mauritian households. In addition, the ministry of agriculture can also give technical advice on the way to plant vegetables and rear animal at home. Roof gardening can be promoted due to lack of land in urban areas. This can help to reduce household expenditure on fresh vegetables. Moreover, this measure can also help to reduce the imports of certain food from abroad.

\subsection{Campaign to Reduce Wastage of Food}

Government can organize advertisement on the local press and newspapers to make people aware about the issue of food security in the island and encourage its citizen to reduce wastage of food. This can help to reduce importation of food from foreign countries. There is a paradox in Mauritius whereby many people waste food while there are others who live below the poverty line. Mauritian can be encouraged to share excess food with people who are in need and this can also help to decrease undernourishment in the country.

\subsection{Aquaculture}

Although land is a limited factor, Mauritius is surrounded by a vast area of sea. However, Mauritius has been underutilizing its marine resources. Mauritius must make full use of its marine resources by promoting activities that can help to increase fish production in our marine areas. Aquaculture has to be promoted in Mauritius since it has been found that local fishermen having been overfishing in our lagoons and with time, the capture of fish in the lagoon has decreased substantially. Aquaculture can be the solution this problem. However, proper training and grouping of fishermen in cooperatives can help in the implementation of such policy. Moreover, aquaculture can have negative impacts on the marine environment and hence government must ensure that such practices do not have such impacts. Fresh water fish production can also be encouraged inland and this will enable to increase fish production as well. Aquaculture at sea has already started in the southeast part of the island by private organizations and it is only done at a very small scale. Other areas at sea must be identified and provided to local fishermen grouped in cooperatives. Moreover, production of oysters is also being done on small scale and expertise is being developed. Fishermen around the island can also be encouraged to take part in such activities. On the other hand, deep sea fishing has to be encouraged and local fishermen must be trained for such initiatives. These measures can help to increase availability and affordability of such products on the local markets.

\subsection{Reducing Impact of Climatic Change}

Climatic Change is considered as a major factor that will inevitably impact on food security in different countries of the world. Although it is very difficult to deal with the different impacts of climate change on agriculture, more research can be carried out to develop crops that are resistant to climate change. Collaborative research and sharing of research among countries in the region can also help to develop expertise in dealing with such phenomenon. Each country in the region can learn from their respective experience in this field. On the other hand, farmers must be provided additional incentives to adopt protected farming. Many farmers in Mauritius are still using traditional ways of agriculture and they must be motivated to use hydroponic culture or greenhouses that can help to control different element of the environment like temperature and control disease that may affect crops that are grown. One of the reasons for not adopting such practices is the high costs involved in such a practice. In this context, government can provide more financial incentives like loans at a preferential rate to these farmers. On the other hand, officers of the ministry of agriculture must provide proper training and technical advice to the farmers using these modern methods of farming.

\subsection{Improvement of Hygiene and Safety of Foods}

The survey has shown that many people have a major concern about the suitability of food that is available in Mauritius. They voice out that the food which is readily available in Mauritius is not hygienic and safe for health. Many people who sell food products in Mauritius do not respect sanitary measures and it may hence constitute a health hazard for the Mauritian population. In recent years, many Mauritians have been affected by food poisoning. In Mauritius, there are many laws that have been promulgated to protect consumers against such risk but the main problem lies in its enforcement. Government officials complain that lack of personnel is responsible for such a situation. In this context, the government must train food producers on the risks involved and the precautionary measures that must be taken to avoid such situations. More people should also be employed so as to enforce the law and this can help to increase the suitability of food in the country. On the other hand, many farmers are using excess of insecticides and pesticides and this can be found in vegetables 
that are being sold on the markets. This can be one of the factors that is contributing in the increasing numbers of cancer cases in Mauritius. Training and use of bio fertilizers and insecticides are possible solutions to reduce such risks in future.

\section{6.0 CONCLUSIONS}

Food is a fundamental right for a human being. Yet there are millions of people around the world who suffer from malnutrition and undernourishment. The problem is much serious in the Sub Saharan countries. Food insecurity has become a major concern for these countries and many researches are being done to understand and find the most appropriate solutions to this problem. Apart from availability of food, efforts must also be made to increase the affordability and suitability of food in different countries. In some countries although food is readily available, people are not able to pay for it since it is too expensive. On the other hand, food which is available must be according to the habits and culture of the people living in these countries. In Mauritius, food is readily available from imports and local production but many people are complaining about affordability and suitability of food. Some local households are much concerned about hygiene with respect to fast food being sold on the streets of Mauritius. In short, all the different aspects of food security must be addressed accordingly.

There is no simple solution to the problem of food security worldwide. Different countries face different context and factors that can affect food security. Consequently, each country must analyze its own context and situation and come up with tailor made solution to this problem. However, sharing of different experiences of different countries in the field of food security will inevitably help to learn from each other and enable to develop solutions that must be adapted rather than adopted to a specific context.

Political attention to this problem is vital and the development of appropriate government policies can help to reduce the negative impacts of food insecurity in a country. However, government policy alone cannot be successful since many stakeholders are concerned with this issue. If farmers do not take advantage of the incentives and training being provided by the government then such government policies may not be effective. Customers must be able to get access to affordable prices of food products and inappropriate distribution channels can contribute to exacerbate the problem of prices of food products. Personal initiatives like home gardening can help to increase food security to some extent in the country. This can enable many household to get fresh vegetables and they can also control the suitability of the food by monitoring the level of pesticides and insecticides that they can use or by adopting bio culture practices which are free from any pesticides, fertilizers and insecticides.

\section{REFERENCES}

[1] Claudia Ringer et al(2010), Climate Change impacts on Food Security in Sub Saharan Africa

[2] Insights from Comprehensive Climate Change Scenarios, International Food Policy Research Institute

[3] Clover J (2003), Food Security in Sub Saharan Africa, Africa Security Review, Vol 12(1)

[4] Defi Plus,(Local Mauritian Newspaper), 24 February 2014, "Piraterie : Chute des attaques sans conséquence sur les exportateurs",

[5] Earth Policy Institute. Lester R. Brown. August 08, 2012. Plan B Updates. Rising

[6] Temperature Raising Food Prices.

[7] FAO (2014), The state of Food Insecurity in the World

[8] H. Charles J. Godfray, et al.(2010), Food Security: The Challenge of Feeding 9 Billion People, Science Magazine, Vol 327

[9] Jan de Graaff-, Aad Kessler and Jan Willem Nibbering(2011), Agriculture and food security in selected countries in Sub Saharan Africa; diversity in trends and opportunities, Food Security -The Science, Sociology and Economics of Food Production and Access to Food, Springer Publishing

[10] Mwaniki A.(2008), Achieving Food Security in Africa, Cornell University

[11] NESC(July 2013), Food Security The Challenges For Mauritius, NESC Report 24

[12] Sasson A.(2012), Food Security for Africa: An Urgent Global Challenge, Vol 1:2

[13] UNDP (2012), Africa Human Development Report - Towards a Food Secure Future

[14] United Nations Environment Programme (2009). The Environmental Food Crisis - The environment's Role in Averting Future Food Crises: A UNEP Rapid Response Assessment 